Division of Social Science

The Hong Kong University of Science and Technology

Working Papers in the Social Sciences, No. 42

\title{
The Tibet Question in Post-Summit Sino-American Relations
}

by

Barry Sautman

Division of Social Science

Hong Kong University of Science and Technology

Clear Water Bay

Kowloon, Hong Kong

18 August 1998 


\section{The Tibet Question in Post- Summit Sino-American Relations}

(Draft of August 14, 1998)

Barry Sautman, Division of Social Science Hong Kong University of Science \& Technology

Clearwater Bay, Kowloon, Hong Kong

Tel: 852 2358-7821; Fax: 852 2335-0014

E-mail: sobarrys@ust.hk 


\begin{abstract}
The recent intense US interest in the Tibet Question arises largely from the successful politicization by the Tibetan exiles and their Western supporters of popular American fascination with Tibetan Buddhism and culture. A almost uniform support for the Dalai Lama's political position within the US Congress and mass media has been reflected in US Administration Tibet policy in the 1990s. This one-sided approach has produced an unremitting hostility by the PRC government toward foreign and, particularly US, involvement in PRC/Tibetan exile affairs. At the same time that "Tibet fever" crests in the US, however, the centrality of China in US foreign policy has recently caused the US $t$ ) incrementally move toward a more balanced view. The period of the two US/China presidential summits has also seen indications of a new willingness by PRC leaders to allow for indirect American involvement in reaching an accomodation that will allow for PRC/exile negotiations.
\end{abstract}


The Tibet Question in Post-Summit Sino-American Relations

\section{Introduction}

At the end of a joint press conference held by Presidents Clinton and Jiang during their summit in Beijıng on June 27, 1998, Jiang Zemin asked to take an extra five minutes to discuss the subject of Tibet. After speaking of the role of the PRC central government in the modernization of Tibet, he stated

[A]s long as the Dalai Lama can publicly make a statement and a commitment that Tibet is an inalienable part of China and that he must [sic] also recognize Taiwan as a province of China, then the door to dialogue and negotiation is open. ${ }^{1}$

These brief remarks surprised US officials. A taboo had been broken in Jiang's having broached the: Tibet Question with a foreigner -and live on PRC national television to boot. Jiang's statement has subsequently provided a basis for US officials to continue to press the Tibet issue with PRC leaders. ${ }^{2}$ It also caused a sensation among Tibetans in Beijing and Tibet. As a result of the remarks, Tibetans have been able to speak less guardedly about the sensitive Tibet Question and are more optimistic about the possibility of a breakthrough in the four-decades old dispute between the PRC and the Tibetan exile administration in Dharamsala, India. ${ }^{3}$

Jiang Zemin had said nothing new in stating that negotiations with the Dalai Lama could begin if the latter openly stipulates that Tibet 
is part of China. The tone and setting of his remarks, however, markedly departed from recent practice. Just a day earlier, Ye Xiaowen, China's top official in charge of religion, had attacked the Dalai Lama as a duplicitous apostate bent on restoring feudalism in an independent Tibet and had criticized US officials as irresponsible for raising the Tibet Question. ${ }^{4}$ In contrast, Jiang did not denounce the Dalai Lama and made his remarks in direct response to President Clinton's raising of the Tibet issue. Jiang did not require the Dalai Láma to state that Tibet had been part of China since the Thirteenth Century, as the PRC asserts. Observers, including the Dalai Lama's representatives, viewed Jiang's remarks as "startling" and a sign of "positive movement in Beijing," attributable in part to US efforts. Rumors quickly surfaced that the exiles would send a delegation to Beijng to set the stage for negotiations. ${ }^{5}$

This paper examines US interest in the Tibet Question and the Chinese response. It argues that official US involvement largely reflects a popular American interest in Tibet's religion and culture that has become politicized through the effort of the exiles to internationalize the Tibet Question. Domestic pressures emanating from this single-issue constituency and antagonism toward the last major Communist-ruled state have produced one-sided US support for the Tibetan exile cause for more than a decade, despite the Dalai Lama's vacillation on whether to seek independence or greater autonomy for Tibet. The PRC response to 
US interest in the issue has been concomitantly hostile. The Tibet Question has thus been a constant irritant in US-China relations. There are, however, recent indications of changes on both sides. While domestic pressures in the US have made the Tibet Question increasingly important to the US-China relationship, Sino-American relations have become central to US foreign policy. US policy has accordingly begun to shift to a more balanced stance, which is also a precondition for the US having any role in facilitating negotiations on the Tibet Question. As its relationship with the US has become more crucial, China also seems to have opened a window of opportunity for third parties to indirectly participate in forging a compromise solution to the Tibet Question.

\section{The Tibet Question in the United States}

A "Tibet fever," spurred by several feature films on the Tibet Question, appeared in the US in the late 1990). "Seven Years in Tibet," by French director Jean-Jacques Annaud, depicts the friendship between the very young Dalai Lama and an Austrian Nazi mountain climber who became the boy's tutor. The film's principal adviser was Tenzin Tethong, long the Dalai Lama's representative in international fora and ex-head of the exile Kashag (cabinet) ${ }^{6}$ "Kundun," by US director Martin Scorcese, is an authorized biography of the young Dalai Lama. The politically sympathetic screenplay writer Melissa Mathison met several times with the Dalai Lama to receive his advice about the film. ${ }^{7}$ These 
films portray the PRC government as villainous and are regarded by it as inaccurate, separatist propaganda ${ }^{8}$. Its efforts to curtail their distribution have been unavailing, however. ${ }^{9}$ Indeed, "Seven Years in Tibet" had a commercial run on Chinese soil, in Hong Kong, and pirated tapes have entered the mainland from there.$^{10}$ Major US studios have scheduled five more films about Tibet, including one that depicts action hero and reincarnate high lama Steven Segal as a 1960s CIA agent directing Tibetan exile guerrillas against the Chinese. ${ }^{11}$ The Tibet Question will literally be before the public eye well into the next century.

The films are emblematic of growing support for Buddhism and the Dalai Lama's cause among leaders of popular US culture. While internationally Buddhist leaders bemoan a waning of faith among Buddhism's quarter billion adherents, ${ }^{12}$ it is the fastest growing religion in the United States. ${ }^{13}$ Estimates in the mid-1990s ranged from 500,000 to two million. The former figure almost certainly refers to US-born converts to Buddhism, while the latter figure includes Buddhist immigrants from Asia. ${ }^{1415}$ In 1989-1997, Buddhist teaching centers in the US more than doubled from 429 to $1,062 .{ }^{16}$ Many converts follow Tibetan Buddhism and among them are film stars, such as Richard Gere, Sharon Stone, Harrison Ford and Goldie Hawn, who associate with the Dalai Lama. ${ }^{17}$ Musicians, such as the Beastie Boys, U2, Patti Smith, Alanis Morissette, Sting, Herbie Hancock and Phillip Glass, have staged 
huge "Concerts for a Free Tibet" in 1996, 1997 and $1998 .{ }^{18}$ Leading fashion designers contribute their creations to fund-raising efforts for Tibetan exile causes. ${ }^{19}$ A cottage industry of popular books on Tibet and Tibetan Buddhism has emerged. ${ }^{20}$

The leap of interest in all things Tibetan has had a political effect in the US. The International Campaign for Tibet, the main organization coordinating support for the Dalai Lama's program, reported a membership jump from 2,000 in early 1997 to 16,000 in early 1998 to 25,000 in mid-1998. ${ }^{21}$ Its website went from 500 to 60,000 hits a week during the peak run of "Seven Years in Tibet." ${ }^{22}$ Students for a Free Tibet grew from a dozen chapters in 1993 to 45 in 1994, 80 in 1995 and 400 in 1997. There are also "Friends of Tibet" organizations in major US cities. An International Committee of Lawyers for Tibet provides arguments for Tibetan self-determination. The Committee of 100 for Tibet assembles Nobel Prize winners, including Desmond Tutu, Elie Wiesel, Jose RamosHorta and Mairead Maguire, as well as notables, such as Ramsey Clark, Jeane Kirkpatrick, Oliver Stone, and Coretta Scott King. The US Tibet Committee has attempted a consumer boycott of PRC goods. ${ }^{23}$

Demonstrations demanding that China withdraw from Tibet are prominently covered in the US media and pro-exile polemicists have a lockhold on discussion of the Tibet Question in key US newspapers. ${ }^{24}$ Effective lobbying has allowed the Dalai Lama's supporters to gain the 
ears of many public figures. During his first twenty years in exile (19591979), the Dalai Lama was not allowed to enter the US. Now legislators welcome him to Congress and he has met with the US President every year since $1991 .{ }^{25}$ Scores of members of Congress participate in a Tibet caucus led by Benjamin Gilman (R-NY), chair of the House International Relations Committee, and Jesse Helms (R-NC), chair of the Senate Foreign Relations Committee. The caucus includes liberals as well, such as Senators Russell Feingold (D-WI) and Daniel Moynihan (D-NY), and is part of a larger group that has produced a blizzard of anti-PRC legislation. ${ }^{26}$ Few members a void this trend. For example, in March, 1998, the House voted 397-0 to call upon the President to introduce a resolution before the UN Commission on Human Rights condemning PRC human rights practices (H Res 364). The Senate (S Res 187) passed a similar measure, knowing that the President had concluded that a UN resolution had no chance of success and would harm US-China relations ${ }^{27}$. A month later, the Dalai Lama endorsed the President's decision and even stated that China should not be publicly condemned. ${ }^{28}$ The idea that China is wholly responsible for the Tibet conflict goes unchallenged among US politicians. Congressional committees have held many hearings in which no witness diverges from Tibetan exile administration positions, ${ }^{29}$ a situation acknowledged by the head of one such committee. ${ }^{30}$ In contrast to the late 1980 s, when the executive 
branch at times took issue with some Congressional assertions about Tibet, ${ }^{31}$ US administrations in the 1990 s have seldom objected to even the most fanciful Congressional claims. From 1991, when Congress attached a clause to the Foreign Relations Authorization Act (PL 102-138) that characterized Tibet as "an occupied country," it has passed resolutions that demand that the US establish diplomatic ties with the Tibetan government-in-exile. After a three-year effort, US lawmakers succeeded in 1997 in forcing the appointment of a Special Coordinator for Tibet whose duties include liasing with Dharamsala. Congress supports the uniformly pro-Dalai Lama Tibetan-language broadcasts of Voice of America and Radio Free Asia, provides scholarships to bring Tibetans vetted by the exile administration to ('S universities and subsidizes exile projects. $^{32}$

As one US official has noted, "Tibet is an issue of rising salience and prominent visibility on the (US-China) agenda." ${ }^{33}$ US Secretary of State Madeline Albright had "quite lengthy and intensive discussions on Tibet" with PRC leaders in Beijing in April, 1998. ${ }^{34}$ Just before his trip to China, President Clinton described the Tibet Question as "a big thing" for the US and promised to seek "autonomy with integrity" for Tibet. ${ }^{35}$ Rumors were floated about how a US-China summit tradeoff involving Taiwan and Tibet: a joint communique on Taiwan in which the US agreed to scale-back its support, in exchange for the PRC opening talks 
with the Dalai Lama. ${ }^{36}$ As it turned out there was no new joint communique. President Clinton did however state that the US would not support the idea of "two Chinas" or "one China, one Taiwan," would not promote Taiwan independence and would not support Taiwan's entry into any international organization that required statehood for membership (the "three no's," as the PRC terms thern). ${ }^{37}$ President Jiang, perhaps in reciprocation, made his now-famous statement on the Tibet Question. PRC officials hold that Taiwan remains "the most sensitive, most important" issue in US-China relations. ${ }^{38}$ With the acceptance of the "three no's" and scant support in Taiwan for immediate independence, however, something of a modus vivendi on the Taiwan issue has been worked out between the PRC and the US executive branch.

Tibet has thus risen in prominence as a question in US-China relations. It has been an on-again-off-again issue in US-China relations since almost the inception of the People's Republic. From the mid-1950s to the early 1970s, the US trained and armed Tibetan rebels. From the early 1970 s to the mid-1980s, Tibet largely faded from the US agenda during a period of US-China quasi-alliance against the former USSR. ${ }^{39}$ By the mid-1980s, however, US-China amity had begun to erode with the Congress's excoriation of China on issues such as abortion, arms proliferation and the trade balance. Meanwhile, Tibetan exiles hopes that China would negotiate independence were dashed. At the same time, the 
loosening of controls over religion in Tibet allowed nationalist monks and nuns greater opportunities for political organization and exiles an increased freedom to visit and contacts in Tibet. The increase in religious and cultural autonomy spurred the pro-independence forces. ${ }^{40}$

The Dalai Lama's advisers and Western supporters devised a strategy to boost separatism in Tibet by showing that it had world-wide support, while re-kindling international interest in the Tibet issue. The strategy involved encouraging civil disobedience in Tibet, and a steppedup travel schedule for the Dalai Lama, who would seek talks with China on "reasonable" terms and help build support/lobby groups and parliamentary Tibet caucuses. ${ }^{41}$ Internationalization coincided with an increased interest in developed countries in human rights in the developing world and with the decline and fall of Communism outside Asia, which convinced the Dalai Lama and many US leaders that China would be the next domino to fall. ${ }^{42}$ The fierce repression against protests in Tibet in the late 1980s boosted the internationalization effort. "Tibet Fever" is thus not only the culmination of a growth in interest Buddhism and Tibetan culture in the West, but also a fruit of the internationalization strategy.

\section{The Intractable Tibet Question}

The Tibet Question is a difficult issue in US-China relations because it is one of the world's most intractable conflicts. There are a 
number of reasons for this. First, the Tibet Question is a long-running ethnic dispute that has persisted into the post-Cold War era of rising nationalism. Neither China's rulers nor the Tibetan exiles have escaped the nationalist trend. ${ }^{43}$ Under the most favorable circumstances, ethnic conflicts are hard to resolve because they are subject to "ethnic outbidding" in which leaders seek to steal a march on rivals through nationalist one-upmanship. Outbidding escalated the ethnic conflicts that followed the dissolution of the Soviet Union and Yugoslavia ${ }^{44}$ and makes it difficult for most ethnic group leaders locked in potentially secessionist conflicts to advance compromise proposals.

Like several other sharp ethnic conflicts, the Tibet Question also has religious overtones that draw in seekers of religious merit through struggle. Some 70 percent of those imprisoned in Tibet for separatism are monks and nuns. ${ }^{45}$ Disputes in Tibet have covered such political/religious issues as the permissible number of monks (now two percent of the Tibet population) ${ }^{46}$ and the control of lamasery management. ${ }^{47}$ An acrimonious dispute continues about whether the Dalai Lama or the PRC had the right in 1995 to recognize the reincarnation of Tibetan Buddhism's second highest figure, the Panchen Lama ${ }^{48}$ The religious and ethnic aspects of the conflict overlap because chauvinistic Han Chinese regard traditional Tibetan culture as "primitive."49 
Second, the Tibet Question is a sovereignty dispute. Despite the historical ambiguities of the Sino-Tibetan relationship ${ }^{50}$ each side claims the exclusive right to rule the ethnic Tibetan areas. The Tibetan exiles and their supporters assert that Tibetans are a nationality wholly apart from the Chinese. They claim that because Tibet is only part of China "because of the use of force by the Chinese communists, not because of history," as the Dalai Lama puts it, Tibet has a right to independence supported by international law. ${ }^{51}$ The PRC argues that Tibetans have long been part of the Chinese people (zhonghua minzu), that Tibet has been linked to China since the Tang Dynasty (618-906) and has been part of the country from the Yuan dynasty (1234-1368). China points out that international law does not sanction secession. ${ }^{52}$

For internal political reasons, neither side has openly considered trading away significant elements of the bundle of "ownership" rights that it claims. The exiles have stated a willingness to cede to the PRC only the most limited rights in Tibet. These include the right to represent Tibet in the UN and to temporarily station troops on Tibet's borders, although the Dalai Lama did indicate in 1997 that he may be willing to leave "law and order" functions to the PRC. ${ }^{53}$ Thus far the only "concessions" that the PRC has offered are the Dalai Lama's return to Tibet and a sinecure as one of 16 PRC National People's Congress vice-chairmen.${ }^{54}$ The parties, moreover, cannot agree on what territory constitutes "Tibet." 
China limits it to the area controlled by the Dalai Lama prior to 1950 ("political Tibet," where 45 percent of all ethnic Tibetans live), while the exiles argue that Tibet includes all areas in which ethnic Tibetans have formed a majority ("ethnographic Tibet"). ${ }^{55}$.

Third, the Tibet Question operates within the wider context of ethnic relations in China. The Chinese government fears that concessions offered to the Tibetan exiles will create opportunities for separatists who operate in Xinjiang and Inner Mongolia. ${ }^{56}$ The Dalai Lama's camp has given the PRC government no peace of mind on that score. It participates in an Allied Committee of Uygur, Mongol and Manchu separatists whose aim is to alienate the bulk of PRC territory. ${ }^{57}$ The Dalai Lama's 1997 visit to Taiwan was warmly welcomed by Taiwan independence groups.

Tibetan exiles, moreover, charge that China pursues the most oppressive policies in Tibet and other minority areas, including physical or cultural genocide and plunder of natural resources. ${ }^{58}$ The Dalai Lama terms the leadership in Tibet, most of whom are ethnic Tibetans, "local authorities [who] are very narrow-minded, very ignorant and ruthless." 59 Officials in Tibet have responded in kind, calling the Dalai Lama an "arch-criminal" and "faithful tool of the international anti-China forces. ${ }^{, 60}$ The parties to the Tibet Question thus find it difficult to conceive of a settlement under which they will work side-by-side in Tibet. Both sides envisage the surrender of the other side. Thus, the Dalai 
Lama has spoken of "the withdrawal of the Chinese regime" following negotiations, ${ }^{61}$ while the PRC, in an approach harking back to imperial policies, ${ }^{62}$ offers the Dalai Lama titles and emoluments, but no power.

\section{Tibet as a Refractory Issue in US-China Relations}

Besides being generally intractable, the Tibet Question has been a hard nut to crack in US-China relations. In contrast to its approach to the Taiwan Question, the PRC has long rejected foreign involvement in solving the Tibet problem. When it first began to negotiate with Taiwan's leaders, the PRC made use of Japanese intermediaries. It publicized the positive attitude of Japanese officials toward the PRC's Nine-Point reunification proposal of 1981 and invited pro-Taiwan Japanese politicians to the mainland for talks. ${ }^{63}$ More recently, China has sought the help of both Singapore and the US help in persuading Taiwan's leaders to deepen negotiations. ${ }^{64}$ China thus does not entirely rule out foreign participation in advancing talks over territorial issues. Why then has China spurned third party efforts at involvement in the Tibet Question?

One reason lies with the PRC exercise of power in Tibet, but not in Taiwan. Taiwan has to be wooed, regardless of how onerous that is for PRC leaders. Taiwan's Lee Teng-hui spurns the idea of "one country, two systems" and demands a "one China, two sovereign entities" an approach unacceptable to the PRC. He conditions reunification on the adoption of 
liberal democratic institutions in the mainland and a rise in its living standards to those of Taiwan. Lee refuses closer practical ties, such as direct air and sea links and seeks to curb the growth of Taiwan investments in the mainland. ${ }^{65}$ At the same time, the forces that stress a distinctly Taiwan identity are increasingly popular and may win the Taiwan presidency in the year $2000 .{ }^{66}$ The PRC thus has scant leverage to employ against its errant province. The US, however, is Taiwan's only ally. The US Congress will certainly not pressure it, but PRC leaders believe that something may be gained by asking the US executive branch to do so.

In contrast, the PRC has great political leverage over the Dalai Lama's supporters in Tibet. During the same period in the mid-to-late 1990s in which Tibetan exiles capitalized in the West on earlier gains from the internationalization campaign, visible separatism in Tibet abated. There were "riots" in Lhasa during the first half-dozen years of internationalization, but no major demonstrations in Tibet since 1993. Repression, political persuasion, acculturation and social mobility have contributed to the remission of separatist activity. The Dalai Lama has estimated that he has twenty more active years. ${ }^{67}$ Many PRC officials argue that economic and cultural change in Tibet will ameliorate separatism and that the passing of the Dalai Lama will end the Tibet Question. Some pro-Dalai Lama figures agree: Lord Ennals, the late 
head of the Tibet Society in Britain, remarked that "Without the Dalai Lama, it would be very difficult for the pro-Tibet organizations to keep going." ${ }^{68}$ PRC leaders believe time to be on their side with regard to Tibet, while the opposite is true about Taiwan. China has thus been less inclined to seek the aid of foreigners on the Tibet Question.

PRC unwillingness to accept the existence of a Tibet Question with international implications has also stemmed from its leaders having carried over a distinction between Tibet and Taiwan that they first made in the early 1980s. Tibet, they said, has been "liberated," while Taiwan has yet to be. PRC spokesman have given this reason for not acceding to the Dalai Lama's request that the "one country, two systems" solution be applied to Tibet, holding that it would be a social evolutionary step backward for Tibet, but a step forward for Taiwan. ${ }^{69}$ Such thinking is still evident among PRC officials who deal with Tibet. For example, Raidi, deputy CCP head in Tibet and chair of its People's Congress, has said

Tibet leapt over several historical stages to enter into the initial stage of socialism in a short period of several decades ... 'One country, two systems' is only suitable for the regions of Hong Kong, Macao and Taiwan; it is not suitable for Tibet. ${ }^{70}$

PRC social evolutionists expect that Taiwan, being at a lower stage of political development because of its detachment from the motherland, would be politically involved with foreign states. They have deemed it unnatural for Tibet, as a region at the higher "historical stage" 
of attachment to the motherland, to have foreigners play a role in determining its political future. Until recently, then, the PRC held that a Tibet Question could not exist, because its existence would imply that foreigners may have some influence on political outcomes for Tibet.

\section{US Reluctance to Play a Role}

While the Taiwan issue was formalized in three US-PRC communiques of the 1970s and early 1980s that prescribe how the US is to interact with Taiwan, the PRC has never explicitly acknowledged a Tibet Question in US-China relations. Even had the PRC done otherwise, conflicts over human rights and other issues after 1989 precluded it from regarding foreign states as levers for realizing negotiations over the Tibet Question. This has been especially true as to the US, which despite its official recognition of Chinese sovereignty over Tibet, ${ }^{71}$ has been a bulwark of support for the Tibetan exile cause. At the same time, because of the growing impact of a US "Tibet Lobby," the US has been reluctant to play a role in the pre-negotiations process. Officially, it feigns ignorance as to why no negotiations have taken place and leaves it to the parties to solve their problems. ${ }^{72}$ Meanwhile, the US has facilitated or is trying to bring about negotiations over a number of longstanding, ethnic conflicts, including Northern Ireland, Bosnia, Israel/Palestine and Cyprus. The role of the US in the peace agreement in Northern Ireland is instructive. Until recently Britain had complained that pro-Irish 
nationalist US interventions, made in response to the Irish-American Lobby, interfered in UK internal affairs. ${ }^{73}$ As a UK newspaper observed about the crucial role that was to be played by the US in the Northern Ireland peace process, "the real transformation was when Washington grasped that there were two sides to the Ulster argument" and began to give equal treatment to the Ulster Unionists. The British could then recognize that the US had "assumed the mantle of honest broker". ${ }^{74}$

While the US has had a crucial role in facilitating peace accords in and around Europe, it has been more circumspect about participation in some equally long-running and bloody disputes in Asia, where US interests seem more attenuated. Even under such circumstances, however, changes in the political balance can alter US willingness to become involved. In November, 1997, Secretary of State Albright firmly ruled out US mediation between India and Pakistan to resolve the Kashmir dispute, despite being pressed by long-time ally Pakistan. ${ }^{75}$ After the "Hindu nationalist" BJP came to power in India, however, US Ambassador to the United Nations Bill Richardson stated that, while the US has no wish to volunteer as mediator, it would consider ways to help if asked by India and Pakistan. ${ }^{76}$

In the case of Tibet, there are no apparent strategic US interests involved. For example, there is practically no US investment in Tibet. ${ }^{77}$ The chair of the Senate Foreign Relations Committee Asia-Pacific Subcommittee, 
Senator Craig Thomas (R-WY), has stated, however, that lack of US strategic interests aside, concern among Americans about human rights in Tibet is sufficient to generate continuous official interest in the Tibet Question. ${ }^{78}$ The Senator implicitly acknowledged the influence of the Tibet Lobby in impelling the US to adopt a less-than-balanced approach that has inhibited it from playing a greater role in the search for answers to the Tibet Question.

\section{The Tibet Lobby and US Policy}

The US Buddhist community is the base of the Tibet Lobby. US Buddhists are more educated than the average American $^{79}$ and are often highly articulate and inclined to political participation. Some are found among the ranks of legislative aides to members of the Congress. USborn Tibetan Buddhists, moreover, often bring to the Tibetan exile cause a convert's zealotry. They are also affected by Tibetan exile internal politics. The public mainstream position among exiles is to support the Dalai Lama's call for negotiations to implement "genuine autonomy" for Tibet. This position is advanced on the grounds that independence is only possible if China breaks apart or becomes a liberal democratic state and an independent Tibet may not be economically viable. ${ }^{80}$ The exile administration includes not only public adherents of this position, but also proponents of independence. ${ }^{81}$ Leaders of this bent who have not been given posts are nevertheless treated by the exile administration as a 
powerful and popular "loyal opposition." The exile leaders also tell the world that most Tibetans in Tibet favor independence, ${ }^{82}$ although whether this is so cannot be convincingly verified. In short, the exile administration undercuts its own "moderate" position by representing it to the world as a minority view among Tibetans.

Even with this understood, the internal political situation that the exile administration presents to the world diverges from the reality of barely concealed support for independence among exile leaders. In 1988, in the Strasbourg Proposal, made before the European Parliament, the Dalai Lama stated that "The whole of 'Tibet ... should become a selfgoverning democratic political entity founded on law ... in association with the People's Republic of China. ${ }^{83}$ After he abandoned the Strasbourg Proposal in 1990, the Dalai Lama refused to say whether he was reverting to support for independence ${ }^{84}$ The exile parliament, however, endorsed "complete independence" as the official goal in $1992 .{ }^{85}$ Many of the Dalai Lama's subsequent statements indicate that he has not wholly abandoned a pro-independence stance. In the mid-1990s, he stated that "Our stand is still for independence," "Tibet is not part of China," "Tibet is independent in cultural, geographical, linguistic and racial terms," "experience shows that independence is the only real answer" and "independence remains our goal". ${ }^{86} \mathrm{He}$ also put it that "Tibet is not part of China," "[T]he entire international community should speak out in 
support of Tibet's independence" and "Of course we have the right to regain our independence. ${ }^{, 87}$ In the late 1990s, the Dalai Lama speaks of "genuine autonomy," but has also stated that "we Tibetans have every right to independence" 88 and "independence is our historic right" These pronouncements might be interpreted as mere assertions that, although Tibetan independence has been usurped, the exiles are willing under the proper conditions to waive their right to re-establish it. ${ }^{90}$ Other actions, however, belie this interpretation.

The Dalai Lama has been quoted as telling a Barcelona audience that "he would be willing to renounce in the short-term the cause of Tibetan independence, if Beijing would guarantee the establishment of an autonomous Tibetan government" ${ }^{91}$ This approach recalls the frank statement made by the Dalai Lama's younger brother (and longtime exile leader) Tenzin Chogyal to a French reporter "Let us first of all achieve autonomy. Then we can throw out the Chinese!"92 In May 1997, the Dalai Lama received participants on a "March for Tibet's Independence" in Fishkill, New York. The march was sponsored by the International Tibet Independence Movement (ITIM), an organization led by two Indiana University professors, one of whom is Thubten Jigme Norbu, the Dalai Lama's eldest brother. ${ }^{93}$ An internationally publicized ITIM report quotes the Dalai Lama as telling the marchers 
People must talk about independence. That is good. We have the right to ask for independence, but we need to think of our methods to struggle for independence. Only prayers will not get independence, and only slogans will not get independence.

The marchers' report added "His Holiness stressed that Tibetans must carefully and systematically construct and implement a method to pursue independence". ${ }^{94}$ No objection to this report was offered by the exile administration.

In April 1998, the Dalai Lama visited six Tibetan Youth Congress hunger strikers in New Delhi. The TYC seeks "complete independence." Its leaders explicitly advocated terror ism in the 1980s and endorse "the use of force" today. ${ }^{95}$ During earlier TYC hunger strikes, the Dalai Lama asked participants to end their fast. (On this occasion, the Dalai Lama did so as well, but added that he could not suggest an alternative and is in fact "confused." He also praised the motivation and determination of the hunger strikers. The Western media accurately appraised his tacit acceptance of the hunger strikers' tactic and motives--one of which is surely to pressure the Dalai Lama to again endorse "complete independence"--as a boost to pro-independence forces ${ }^{97}$ It is unlikely that the Dalai Lama saw it in any other light.

The ostensible division between advocates of "complete independence" and those who formally subscribe to the "middle way" is thus unclear. Not surprisingly, PRC spokesmen contend that "The high 
degree of autonomy advocated by the Dalai Lama is in essence a two-step strategy for Tibetan independence. ${ }^{98}$ US Special Coordinator for Tibet Gregory Craig has put it more diplomatically in stating that the Dalai Lama has been sending "mixed signals" to the PRC leaders. ${ }^{99}$ A longtime US supporter of "complete independence" also recognizes this phenomenon, observing that many exile leaders "privately support independence but publicly maintain a covenant of silence or send out mixed messages". ${ }^{100}$

This ambiguity has made it difficult for PRC leaders to agree to negotiations. The PRC has had a consistent position, first enunciated by Deng Xiaoping in 1979: there can be negotiations over all issues other than independence, but only if the Dalai Lama accepts that Tibet is part of China. ${ }^{101}$ PRC officials express exasperation that the world is convinced that the Dalai Lama has abandoned the fight for independence and therefore places the onus on China for not proceeding with negotiations:

The Dalai Lama tells the world that he only wants autonomy and not independence. But this is only for the rest of the world to see. In talks with us he has never said that he renounces independence, but the world does not believe us. ${ }^{102}$

Without an unambiguous exile administration commitment to its proclaimed goal of "genuine autonomy," the Dalai Lama's US representatives have had no incentive to discourage pro-independence activism among their American supporters. Some representatives hold 
that international support would erode were the Dalai Lama to explicitly renounce independence ${ }^{103}$ and encourage members of Congress who are plus royaliste que le roi in insisting that China grant Tibet independence. ${ }^{104}$ The idea of "complete independence," rather than an autonomous Tibet within China, has thus carried the day within US Tibet Lobby organizations. Among the many US politicians who want nothing short of a "Free Tibet," a PRC/exile "peace process" involving a new compromise approach would seem otiose. For its part, the executive branch has had to consider whether any idea that it takes up may alienate Congress. The US Special Coordinator for Tibet has nonetheless indicated that, if it would help advance the likelihood of negotiations, the Administration would exert pressure not only on China, but also on the Tibetan exiles. ${ }^{105}$ Clearly, China would have to be pressed to grant concessions and the Dalai Lama would have to break with the extremist forces, as every leader who has ever successfully made a breakthrough to negotiations anywhere in the world has done.

It is only very recently that a step toward US even-handedness has become possible and it is the perception of even-handedness that will be determinative of whether a third party can play a bridging role in an ethnic conflict. Recently, Norway offered to mediate the Tibet Question. Norway, however, has been one of the most explicit supporters of the Dalai Lama among states; for example, in the award of his 1989 Nobel 
Prize and by sponsoring Tibetan exile radio broadcasts. Not surprisingly, the Chinese government refused Norway's offer. ${ }^{106}$

\section{The Role of the US in the Search for Negotiations}

Recent signs of a change in attitude toward foreign concern may presage a greater pragmatism on the part of the PRC leadership in dealing with the Tibet Question. To many Tibetan exiles, efforts at conciliation are necessarily unavailing because there are no "moderate" Chinese leaders on the question of Tibet. ${ }^{107}$ The Dalai Lama, however, has periodically singled out certain Chinese leaders as "moderates," including former CCP General Secretary Hu Yaobang and ex-United Front Work Department head Yan Mingfu. He has also referred to the "openmindedness" of Premier Zhu Rongji. ${ }^{108}$ Western media have identified other leaders as Tibet Question "moderates". ${ }^{109}$ Internal politics have also produced periods of lessened Chinese antagonism toward the exiles.

Chinese attitudes are also a function of the stance taken by the Dalai Lama at a given time. For example, in 1978, he stated that the welfare of Tibetans should be the primary consideration in negotiations, signaling a de-emphasis of the goal of independence. Deng Xiaoping responded by inviting the Dalai Lama's delegates to visit Tibet. In contrast, the Dalai Lama's references at Strasbourg to Tibet's "right to independence" were seen as an encoded demand for independence. ${ }^{110}$ PRC/exile relations 
were thrown into a nosedive by the Dalai Lama's 1995 decision to preempt the PRC by naming a new Panchen Lama.

Internal Chinese politics and the attitudes of the Dalai Lama and third parties will also influence the degree of any new PRC opening on Tibet. Western journalists in 1998 perceived more latitude for Chinese to discuss politics than at any time since 1989 , attributing this liberalization to an upturn in the fortunes of political reform after Jiang Zemin's defeat of political rivals Chen Xitong and Qiao Shi. ${ }^{111}$ Whatever the cause of the change, there is probably greater scope now for discussion of even a subject as sensitive as Tibet, assuming an agreement among the discussants that the Dalai Lama must acknowledge that Tibet is an integral part of China.

The PRC also seems more willing than before to permit Westerners to investigate the human rights situation in Tibet. In February, 1998, three American clergymen visited Tibet to enquire into religious freedom, a trip facilitated by the US government. ${ }^{112}$ The American chairman of the US-China Foundation for Aiding Impoverished Areas in Tibet was received by a large number of high Tibetan regional officials April. The European Union sent a human rights delegation to Tibet in May. ${ }^{113} \mathrm{~A}$ group of Danish politicians critical of China's human rights records visited Beijing and Tibet in August and found that Tibet and the Dalai Lama are no longer "taboo" topics. Chinese leaders answered their 
questions "in a remarkably open and frank manner. ${ }^{114}$ Mary Robinson, UN High Commissioner for Human Rights visited Tibet in September $1998 .{ }^{115}$ In 1998, also, the Beijing journal China's Tibet published a piece by a Chinese American that was expressly devoted to the "Tibetan Issue", ${ }^{116}$ whose existence the PRC previously denied. ${ }^{117}$ The article supported the PRC position on 'Tibet. It also approvingly repeated President Clinton's October, 1997 statement that the US has no political goals with regard to Tibet, but engages in "constructive negotiation" over issues such as religious freedom and the preservation of culture in Tibet, the two matters that the Dalai Lama holds central to his own concerns.

\section{Conclusion}

Jiang Zemin's June, 1998 summit press conference statement about Tibet is one indication among several of greater PRC receptivity to a degree of foreign involvement in helping to deal with the Tibet Question. Another indication is that although the Chinese government still publicly denounces the US Special Coordinator on Tibet before the Jiang's statement, ${ }^{118}$ Chinese officials soon thereafter were privately praising his efforts to foreigners. ${ }^{119}$ These officials doubtless appreciate that the Clinton Administration, in its diplomatic efforts concerning Tibet at least, is taking a more even-handed approach than in the past. The Special Coordinator, for example, has concluded that the "one country, two systems" approach urged by the Dalai Lama is probably not realistic for 
Tibet and that the exiles will likely have to settle for a lesser degree of autonomy for Tibet than is granted to Hong Kong. ${ }^{120}$

Whether the US administration still regards itself as too politically constrained to play a constructive role, if called upon to do so, remains to be seen, however. Officials realize the profound effect that a Tibet settlement would have on US-China relations, ${ }^{121}$ but perhaps underestimate the degree to which a settlement that returns the Dalai Lama to Tibet would be popular among his supporters, even if it falls short of fully realizing the Dalai Lama's political goals. Whatever Tibet Lobbyists may say about the need for a "Free Tibet," Tibetans would greet with acclaim any settlement that allows the Dalai Lama to return to a more autonomous Tibet. ${ }^{122}$ If the US administration takes on the domestic political risk, it could convince the Dalai Lama to break with those exile forces whose actions obstruct the road to negotiations. He is uniquely positioned among world leaders to take a step of this kind, enjoying as he does a religious-based prestige that insulates him from successful ethnic outbidding. US pressure would in any case inevitably cuts both ways. It can gain the cooperation of the Dalai Lama only if the PRC offers concessions that make his compromises politically palatable. The US can thus assist both sides by suggesting an acceptable exchange of concessions. PRC concessions need to address the Dalai Lama's greatest concern, the shifting population balance in Tibet and its effect on 
the survival of Tibetan culture. The exiles' concessions would involve assurances to the PRC that they no would longer seek to detach Tibet from China. ${ }^{123}$ The substantive negotiations that would follow would focus on the scope of autonomy for Tibet, particularly on those aspects most relevant to demographic, religious and cultural issues.

The growing "Tibet consciousness" in the US has pushed the Tibet Question to the top of the US agenda China human rights issues. ${ }^{124}$ For the US to reach a stage where it can approach the parties with proposals for compromise, however, conditions still need to be fulfilled by China and the US. PRC leaders will first have to conclude that the Tibet Question is not self-liquidating, that it will not simply dissolve with the passage of time-- as few, if any, ethnic conflicts have done. The PRC government is now much more image conscious that it was even a few years ago. ${ }^{125}$ It also understands the need to reduce potential areas of political instability during the period of social instability that has accompanied the deepening of the economic reform. One promising path for the PRC to achieve a respite from the need to constantly defend its record and to reduce its political risk is to "mobilize all forces that can be mobilized" on the diplomatic front to bring about successful negotiations over the Tibet Question.

US policymakers will have to grasp the possibilities created by a stabilized leadership in China and by the improvement in US-China 
relations generated by the summits. Periods of relative domestic political stability in China and periods of relatively amicable relations between the US and China have moved in cycles and the positive phases of the two cycles have not always coincided. If the final years of the millenium prove to be an era of good feeling between the US and China, they will present an unprecedented opportunity for a cooperation in solving the Tibet Question. 


\section{Endnotes}

1 "We are Building a Friendship that will Serve our Descendants Well': Excerpts from the Clinton-Jiang News Conference," Washington Post (WP), June 28, 1998, p. A22.

2 "Transcript of June 29 White House Briefing by Kristoff, Bader, Roth, Shirk," U.S. Newswire, 30 June 1998; "China's Tang Reassures U.S. on Weapons," Reuters, 27 July 1998. For the favorable US appraisal of Jiang's remarks, see the statement of Jeffrey Bader, Director of Asian Affairs, National Security Council, in $M S N B C$, "Tibet Sees Progress," 29 June 1998

${ }^{3}$ Author's interviews with retired and serving officials and intellectuals in Beijing and Lhasa, 28 June-13 July, 1998.

4 "China Lashes Out at Tibet Critics," United Press International (UPD), 26 June 1998; "' One country, two systems' not applicable to Tibet," Xinhua, 26 June 1998.

s “US works for China-Dalai Lama Talks," Associated Press (AP) 31 July 1998; Robbie Barnett, "Beijing Closer to Tibetan talks," South China Morning Post" (SCMP), 7 August 1998, p. 12.

${ }^{6}$ Carolyn Said. "Trying to Save Tibet," San Francisco Chronicle (SFC), 20 February 1998, p. 1.

${ }^{7}$ Megan Rosenfeld, “'Kundun': the Scenic Route to Tibet," WP, 16 January 1998, p. B01. Rick Lyman, "In Two Looks at Tibet, No Sign of Shangri-La," New York Times (NYT), 7 September 1997, p. 60.

8 " Tibetan official details 'fabrications' in Hollywood film," Xinhua, 8 April 1998, in BritishBroadcasting Corp./Summary of World Broadcasts (SWB), 9 April 1998, FE/D3197/G.

${ }^{9}$ Robert Welkos and Maggie Farley, "Insulted by Films, Beijing Orders Halt to Studio Deals," Los Angeles Times (LAT), 31 October 1998, p. 1.

${ }^{10}$ John Krich, "From Tibet to Tinseltown," San Francisco Examiner, 22 October 1997, p. C1.

${ }^{11}$ Shari Sweeney, "The Real Tibet," Plain Dealer, 25 January 1998, p. 14.

${ }^{12}$ Pierre-Antoine Donnet, "Asia: Buddhist World Fights Rearguard Action," AAP Newsfeed, 7 April 1998.

${ }^{13}$ S. Goldenberg, "Buddhas Booming," Guardian, 4 October 1995, p. 2.

${ }^{14}$ Andrew Hermann, "Buddhists See Cup as Half Full," Chicago Sun-Times, 21 January 1995, p. 13. Miranda Haines, "Buddhism Gains Adherents in West," International Herald Tribune (IHT). 26 June 1995, p. 1. 
${ }^{16}$ Jeff Dawson, "Hollywood's Unconvincing Leap of Faith," Guardian, 27 March 1998 , p. 4.

${ }^{17}$ Claire Sobie, "Where Buddha Meets Bablyon," Independent, 2 April 1998, p. 1; Michael Medved, "Hollywood's China Policy," Asian Wall Street Journal (AWSD), 24 June 1998, p. 8

${ }^{18}$ James Sullivan, "Music with a Mission," SFC, 7 December 1998, p. 49.

${ }^{19}$ Tracy Hayes, "Just Say Om," Dallas Morning News, 28 January 1998, p. IE.

${ }^{20}$ Stephanie Schorow, “Today's Cause Du Jour Distracts Attention from Real Issues," Boston Herald, 14 January 1998, p. 1. Jeff Dawson, "Hollywood's Unconvincing Leap of Faith." Guardian, 27 March 1998, p. 4.

${ }^{21}$ Carolyn Said, "Tibetans Find a Helping Home in East Bay," SFC, 6 March 1998, p. 3; "Tibetan Buddhism," August 4, 1998, Transcript No. 98080402-211.

${ }^{22}$ John Horn, "Hollywood Focuses on China Rights," AP, 30 October 1998.

${ }^{23}$ Guy Treblay, "And then Tibet," Village Voice, January 20, 1998, p. 26. Farhan Haq. "Tibetans Confident of Change," InterPress Service, March 10 1998. Carolyn Said, "Tibetans Find a Helping Home in East Bay," NPR Talk of the Nation, op cit.; John Kearney, "The Politics of Shangri-La," WTN, 17 July, 1998; ICLT [International Committee of Lawyers for Tibet], Legal Materials on Tibet, $2 \mathrm{~d}$ ed. (Berkeley: ICLT, 1997).

${ }^{24}$ Jude Carlson, "Tibet in the News," Bullerin of Concerned Asian Scholars, Vol. 24. No. 2 (1992), pp. 25-44.

${ }^{25}$ Dalai Lama Meets US President, Vice President," Agence France Presse (AFP), 13 September 1995. Alison Mitchell, "Clinton Visits Dalai Lama, Informally," NYT, 23 April 1997, p. A3.

${ }^{26}$ Lawrence Kaplan, "The Anti-China Lobty Grows," Weekly Standard, 26 May 1997, pp. 17-20."Anti-China Legislation Moves Through House," CQWR (Congressional Quarterly Weekly Report), Vol. 55. No. 44 (8 November 1998), p. 2777.

27 "House Presses Administration to Keep Up Heat on China," $C Q$ [Congressional Quarterly], 21 March 1998, p. 765.

28 "Dalai Lama wants China Dialogue," AP April 301998.

${ }^{29}$ Hearings of the House International Relations Committee on Tibet/China Negotiations, Federal News Service (FNS), 6 November 1997; Senate Committee on Foreign Relations, Hearing on the Situation in Tibet and Its People (Washington: GPO, S. Hrg 105-124, 13 May 1997); Senate Committee on Foreign Relations, 
Subcommittee on East Asian \& Pacific Affairs. Hearings on the Political Situation in Tibet, September 7, 1995," FNS, 9 September 1995.

${ }^{30}$ Craig Thomas, Interview with the author, 27 March 1998, Washington, D.C. Testimony of Warren Smith at the Senate Finance Committee's hearing on US-China trade relations, 9 July 1998 .

${ }^{31}$ Elaine Scolino, "Beijing is Backed by Administration on Unrest in Tibet," NYT, 7 October 1987, p. A1.

${ }^{32}$ Dalai Lama, "Address to the World Parliamentarians Convention on Tibet . . A April 23, 1997, FNS, 13 May 1997

33 “Albright to Raise Tibet in China Talks," Relters, 26 April 1998.

${ }^{34}$ Jim Mann, "China Balks at Concessions Timed to Clinton's June Trip," LAT, 1 May 1998, p. 1.

35 "Interview of the President with Radio Free Asia." 24 June 1998.

36 “Taiwan for Tibet: Chinese barter," Press Trust of India, 29 April 1998.

37 Jonathan Peterson, "Clinton backs China on issue of Free Taiwan," LAT, 30 June 1998, p. A1.

${ }^{38}$ John Pomfret. "China's Reminder to the U.S.: the Key Issue is Taiwan." IHT, June 24,1998 , p. 6

${ }^{39}$ Tian Dongdong, "The Tibet Issue in Sino-American Relations: United States Policy-making Since Rapprochement," Ph.D. dissertation, Brandeis University, 1995. Xu Guangqiu, "The United Staes and the Tibet Issue," Asia Survey, 37:11 (1997 November), pp. 1062-1077.

${ }^{40}$ Tseten Sharlho, "China's Reforms in Tibet: Issues and Dilemmas," Journal of Contemporary China, Vol.1. No. 1 (Fall 1992), pp. 34-60; Testimony of Warren Smith, Senate Finance Committee hearing on US-China trade relations, 9 July 1998.

${ }^{41}$ Tom A. Grunfeld, The Making of Modern Tibet. Rev. ed. (Armonk: ME Sharpe, 1996).

${ }^{42}$ Molly Gordy, "Everyone benefits from a democratic China," Newsday, 27 April 1994, P. A31.

${ }^{43}$ Zhao Suisheng, "Chinese Intellectuals' Quest for National Greatness and Nationalistic Writings in the 1990s." China Quarterly, no. 152 (December 1997), pp. 725-745. Melvyn Goldstein, The Snow Lion and the Dragon: China, Tibet, and the Dalai Lama (Berkeley: University of California Press, 1997), pp. 84-85.

${ }^{44}$ Lee Metcalf, "Outbidding to Radical Nationalists: Minority Policy in Estonia, 1988-1993," Nations \& Nationalism, Vol. 2. No 2 (1996), pp. 213-234. Stuart 
Kaufman \& John Cotter, "Ethnic Outbidding in Georgia's Ethnic Wars," paper presented at the 1996 Annual Meeting of the American Political Science Association, San Francisco, CA, USA, 29 August-1 September 1996.

45 "Over 3.993 Monks and Nuns Expelled--Religious Repression Continues in Tibet (TCHRD)," World Tibet Network (WTN), '23 May 1998.

${ }^{46}$ Information Office of the State Council, "New Progress in Human Rights in the Tibet Autonomous Region," Beijing Review, 9 March 1998, pp. 12-22.

${ }^{47}$ Ronald Schwartz, Circle of Protest: Political Ritual in the Tibetan Uprising (New York: Columbia University Press, 1994). Human Rights Watch/Asia, China: State Control of Religion (New York: Human Rights Watch, 1997).

${ }^{48}$ Matt Forney, "That's My Boy," Far Eastern Economic Review, 20 June 1996, p. 26

${ }^{49}$ See, e.g., "Greek leader hopes for closer ties with China," Xinhua 20 July, 1998.

${ }^{50}$ Karl Rahder, "The Tibetan Claim to Statehood," Issues \& Studies, Vol. 38. No. 10 (October 1993), pp. 9-14.

${ }^{51}$ Michael Van Walt van Praag. The Status of Tibet: History, Rights and Prospects in International Law (Boulder: Westview Press, 1987). Michael McCorquodale and Nicholas Orosz, Tibet: The Position in International Law (Stuttgart: Edition Hansjorg Mayer, 1994). Warren Smith, Tibetan Nation: A History of Tibetan Nationalism and Sino-Tibetan Relations (Boulder: Westview Press, 1996); Lin Chao-chen, "Dalai: Muqian yu Zhonggong duihua bi fang Tai zhongyao" (Dalai: At present dialogue with the Chinese Communists is more important than visiting Taiwan), Zhongguo Shibao (China Times)(Taipei), 17 July, p. 1.

${ }^{52}$ Wang Furen and Suo Wenqing, Highlights of Tibetan History (Beijing: New World Press, 1984). Cheng Ran, Why Tibet is an Integral Part of China (Beijing: New Star Publishers, 1991). "Tibet-Its Ownership and Human Rights Situation,"Xinhua, 22 September 1992, in $B B C / S W B, 24$ September 1992, FE/1494/C1/1.

${ }^{53}$ Dalai Lama, "Lost World of a Living Buddha," George Magazine (November 1997).

54 “Five Point Policy Toward the Dalai Lama Made Public," Xinhua. 1 October 1981, in BBC/SWB, 29 November 1984, FE/7813/BIV/1.

${ }^{55}$ Goldstein, op cit., p.71; Farhat Yusuf and Monica Byrnes, "Ethnic Mosaic of Modern China: An Analysis of Fertility and Mortality Data for the Twelve Largest Ethnic Minorities," Asia-Pacific Population Journal 9:2:25-47 (1994).

56 June Dreyer, "Assimilation and Accommodation in China," in Government Policies and Ethnic Relations in Asia and the Pacific, edited by Michael R. Brown and Sumit Ganguly (Cambridge: The MIT Press, 1997), pp. 352-391. 
57 "The Allied Committee of Eastern Turkestan, Inner Mongolia and Tibet Meets in New York," WTN, 19 October 1994.

${ }^{58}$ Dalai Lama Ready to Quit Politics if Tibet W ins Autonomy," AFP, 9 June 1998.

${ }^{59}$ Elizabeth Gleick, "Tibet's Exiled Leader Doesn't Mind Being a Hero to Hollywood If It Helps Free His People from China’s Rule." People, 6 April 1998, pp. 106-109.

60 "Dalai Lama Says Talks with Beijing Only Way to Save Tibet," AFP, 28 June 1998; "Tibetan Official Gives Speech to Conference on Dalai Lama's Criminal Activities," Zhongguo Tongxun She, 14 March 1998, in BBC/SWB, 21 March 1998, FE/D3181/S1.

${ }^{61}$ Dalai Lama, "Critical Reflections: Human Rights and the Future of Tibet," Harvard International Review, Vol.17. No.1. (Winter 1994). pp. 46-49.

${ }^{62}$ Lisa Husman, "Territory, Historiography, and the Minorities Question in China," M. A. thesis (University of California at Berkeley, 1993).

63 "Japanese Prime Minister Favors Chinese Communist Party-Kuomintang Talks," Xinhua, 1 October 1981, item no. 100109. "Japanese pro-Taiwan Politician Invited to China," Xinhua, 8 March 1980, in BBC/SWB, 13 March, ME/6369/A3/8.

64 “Singapore's Lee Criticizes Taiwan Lee's Diplomacy," Asian Political News, January 12, 1998; "Jiang Looks for Progress and Prestige from Clinton," SCMP, 9 April 1998, p. 8; Willy Lam, "Cadres to step uf pressure on Taipei," SCMP, May 13 1998, p. 8. Leslie Chang. "Taiwan dreads a sellout as U.S.-China talks near," AWSJ, May 201998 , p. 1.

${ }^{65}$ Willem Van Kemenade, "China, Hong Kong. Taiwan: Dynamics of a New Empire," Washington Quarterly Vol. 21. No. 2 (1998), pp. 105-120. "Taiwan Ruling Party Brushes Off Opposition Gains," AFP, 3 December 1995.

${ }^{66}$ Christopher Hughes, Taiwan and Chinese Nationalism: National Identity and Status in International Society (London: Routledge, 1997).

67 John Burns, "Dalai Lama is all Smiles over Debate," NYT, 29 June 1998, p. A1.

68 "Captain Moonlight's Notebook," Independent, 9 May 1993, p. 21.

${ }^{69}$ Dawa Norbu, "China's Dialogue with the Dalai Lama 1978-90: Prenegotiation Stage or Dead End." Pacific Affairs (PA), Vol. 64. No. 3 (Fall 1991), p. 357.

70 "Tibetan Leaders Raidi, Gyalcan Norbu at Parliament News Briefing," Xinhua, 11 March 1998, in $B B C / S W B, 21$ March 1998, FE/D3181/S1.

${ }^{71}$ Jeffrey Bader, "Prepared Testimony of Jeffrey Bader . . . Before the Senate Foreign Relations Committee," FNS, 13 May 1997. 
72 "Prepared Testimony of Ronald Schwartz ... Senate Committee on Foreign Relations, Subcommittee on East Asian \& Pacific Affairs, Re the Political Situation in Tibet, September 7, 1995," FNS, 9 September 1995.

${ }^{73}$ Adrian Guelke, "The United States, Irish Americans and the Northern Ireland Peace Process." International Affairs, Vol. 72, No. 3 (1996), pp. 521-536. "Gloating China Says Britain Faces Crisis," Reuters, 4 February 1994.

${ }^{74}$ Rupert Cornwell, "Irish Peace Talks: Deal Not Possible without Clinton," Independent, 11_April 1998, p.3

${ }^{75}$ Harbaksh Nanda, "US Rules Out Mediation on Kashmir," UPI, 19 November 1997.

76 “US Envoy Sees Role for Washington in Reducing Regional Tension," SCMP, 6 April 1998, p. 12.

${ }^{77}$ Leonard Cheng, "United States Direct Investment in China: Basic Facts and Some Policy Issues." In The Political Economy of Sino-American Relations: a Greater China Perspective, edited by Y.Y. Kueh (Hong Kong: Hong Kong University Press, 1997), pp. 105-134.

${ }^{78}$ Craig Thomas, Interview with the author, 27 March 1998, Washington, D.C.

79 “Survey Shows Americans a Religious People," UPI, 3 April 1991.

${ }^{80}$ Dalai Lama, "Lost World of a Living Buddha," George Magazine (November 1997).

${ }^{81}$ J. Naqvi, "Dalai Lama Says Autonomy, not Independence, is Goal," Reuters, 12 August, 1993. Bhuchung Tsering, "Looking at the Tibetan Struggle," in Tibet: the Issue Is Independence, edited by Edward Lazar (Berkeley: Parallax Press, 1994), pp. 45-50.

${ }^{82}$ Pierre-Antoine Donnet, Tibet: Survival in Question (London: Zed Books, 1994), p. 185 .

${ }^{83}$ DIIR, Dharamsala and Beijing: Initiatives and Correspondence 1981-1993

(Dharamsala: DIIR Publications, 1994), p. 43.

${ }^{84}$ DIIR, Dharamsala and Beijing: Initiatives and Correspondence 1981-1993 (Dharamsala: DIIR Publications 1994), p. 51, 67.

${ }^{85}$ Tibetan Goal is Once Again Full Independence," Tibetan Review, (TR) Vol. 37. No. 2 (March 1992), pp. 6-7.

${ }^{86}$ Robert Barnett, "Tibet Political Prisoners Total 'Soars to 335," SCMP 14 May 1993, p. 10. John Gittings, "Dalai Lama Wants China Deal," Guardian, 13 May 1993, p. 12. "Dalai Lama Meets Overseas Chinese in Montreal," CNA (Central News Agency), 23 June 1993. Devinder Sharma, "Dalai Lama: China's Attitude More Favorable Now," Jerusalem Post, 15 August 1993, p. 1. 
${ }^{87}$ Robert Whitaker, "Hurd Could Incur Anger of Peking," Independent, 13 May, 1994, p. 5. Silvio Conti, "Berlusconi Meets Dalai Lama Amid Protest," Reuters, 17 June 1994. Leonid Kotov, "Dalai Lama Says Independent Tibet Good for World Peace," Itar-Tass, 18 July 1994. "Breakdown in Sino-Tibetan Negotiations," TIN (Tibet Information Network), 14 September 1994.

${ }^{88}$ Dalai Lama, "Address to the World Parliamentarians Convention on Tibet ... April 23, 1997," FNS, 13 May 1997.

${ }^{89}$ Jeff Bradley, "Exiled Monk Draws Legions," Denver Post, 2 June 1997, p. A01.

${ }^{90}$ Cf. Eva Herzer, "Rule of Law is Gaining in China" NYT, 9 July 1998, p. A26.

91 “China Warns Spain, France over Dalai Lama Visit," AFP, 15 April 1997

Emphasis added. 92 Pierre-Antoine Donnet, Tibet: Survival in Question (London: Zed Books, 1994), p.
188.

${ }^{93}$ Diane Brooks, "Group Marches for a Free Tibet," Seattle Times, 14 April 1998, p. B1.

94 "Marchers'Private Audience with His Holiness The Dalai Lama," WTN, 3 June 1997.

95 Pierre-Antoine Donnet, Tibet: Survival in Que'stion, (London: Zed Books, 1994), p. 186. Ashish Sen, "Tibetan Protestor Dies," Asian Age, April 301998.

${ }^{96}$ John Zubrzycki, "Tibet and the Internal Dissent," SCMP, 30 April 1998, p. 17.

97 "Dalai Lama Meets Tibetan Hunger Strikers, Calls for Talks with China," AFP, 2 April 1998. "Fading Vision: Words Fail Dalai Lama in Face of Tibetan Militancy," Montreal Gazette, 13 April 1998, p. 8.

98 "China Urges Dalai Lama to Do 'Something Useful' for Tibet," AFP, 30 April 1998.

${ }^{99}$ Gregory Craig, Interview with the author, 25 March 1998, Washington, D.C

${ }^{100}$ Edward Lazar, "Self-Determination the Wrong Emphasis," TR, Vol. 38. No. 1 (January 1993), pp. 15-16.

${ }^{101}$ Guy Dinmore, "China and Tibetan Exiles Reopen Talks," Reuters, 22 July 1993.

${ }^{102}$ PRC Foreign Ministry Spokesperson, quoted in J. MacCartney, "Smiling

Globetrotter Winning the PR Battle," SCMP, 30 September 1996, p. 6.

${ }^{103}$ Mainichi Shimbun, "United States Compromise Disappointing," 9 July 1994, in WTN, 15 July 1994. 
104 Testimony of Lodi Gyari Before the Senate Foreign Relations Committee on the Situation in Tibet," FNS, 13 May 1997.

${ }^{105}$ Gregory Craig, Interview with the author, 25 March 1998, Washington, D.C.

106 "No Way Norway," Far Eastern Economic Review, 16 July 1998.

${ }^{107}$ Tashi Rabgey, "Tibetan Deathwatch: Lessons from the Front," Harvard Asia Quarterly (April 1998).

${ }^{108}$ Pierre-Antoine Donnet, "Dalai Lama Hopes for Fresh Dialogue with New Chinese Leadership," AFP, 15 April 1998.

109 John Gittings, "China Throws New Line to Dalai Lama," Guardian, 2 October 1996, p. 11. "China's Future." AsiaWeek, 7 March 1997, p. 18.

${ }^{110}$ Dawa Norbu, "China's Dialogue with the Dalai Lama 1978-90: Prenegotiation Stage or Dead End," PA, Vol. 64. No. 3 (Fall 1991), p. 353, 356.

${ }^{111}$ Steven Mufson, "Debate Blossoms in Beijing Spring," WP, 19 April 1998, p. A1. Jasper Becker, "Shades of a Beijing Spring," SCMP, 16 April 1998, p. 17.

112 “US Clerics Tour Tibetan Prison, Meet Jailed Nuns," Reuters, 26 February 1998.

113 John Gittings, "Analysis Tibet," Guardian, 14 April 1998, p. 15.

114 "Subject of Dalai Lama 'no longer taboo in China': Danish politicians," $A F P$, August 5, 1998.

115 "Statement of Mrs. Mary Robinson - UN High Commissioner for Human Rights to 6 Tibetan Hunger Strikers in New Delhi," WTN, 14 April 1998.

${ }^{116}$ J-Yao Shen, "Tibetan Issue: Lie vs Truth," China's Tibet, Vol.9. No. 2 (1998), pp $10-15$.

117 "Dalai Lama Accused of Insincerity in Request for Negotiations," Xinhua, 19 April 1997, in BBC/SWB, 22 April, 1997, FE/D2899/G.

118 "China hits out at US Tibet official in Albright delegation," AFP, 28 April 1998.

119 Author's interview with a Western social scientist performing fieldwork in Tibet in the summer of 1998 , Lhasa, 12 July 1998.

${ }^{120}$ Gregory Craig, Interview with the authos, 25 March 1998, Washington, D.C.

121 "Dalai Lama Says Independent Tibet Goud for World Peace," Kyodo, 26 April 1998.

122 Interview with a Western social scientist who performed fieldwork in rural and urban Tibet in the spring and summer of 1998, Lhasa, 12 July 1998. 
${ }^{123}$ Barry Sautman and Lo Shiu-hing, The Tibet Question and the Hong Kong Experience, Occasional Papers/Reprints Series in Contemporary Asian Studies no. 127 (Baltimore: University of Maryland School of Law, 1995). Barry Sautman, "The Tibet Question: Meeting the Bottom Lines." Problems of Post-Communism (May/June 1997), pp. 15-24.

${ }^{124}$ Simon Beck, "Tibet on Top of US Human Rights Agenda," SCMP, 24 April 1998, p. 8.

${ }^{125}$ Jim Erickson and Anne Naham, "Playing to the Gallery," Asiaweek, 26 September 1997, p. 64; Maura Moynihan, "High Drama," New Republic, 6 July 1998. 